\title{
Retention Management Of Critical (Core) Employees - A Challenging Issue Confronting Organisations In The $21^{\text {st }}$ Century
}

Janet Chew (E-mail: jchew@ central.Murdoch.edu.au), Murdoch University, Western Australia Lanny Entrekin (E-mail: 1.entrekin@ Murdoch.edu.au), Murdoch University, Western Australia

\begin{abstract}
Employee retention is one of the challenges facing many business organisations today. Many industries are afflicted with high demand for specialised employees and are also suffering high levels of turnover. We have moved into a knowledge-based society where human capital is considered a key resource and a competitive business advantage. The high attrition rate of critical (core) employees is costly to corporations. Loss of these high talent employees results in the stripping of valuable human capital, critical skills and institutional memory. Consequently, companies are giving increased attention to ways of retaining their high performing employees rather than relying on costly replacement and retraining. New paradigm companies recognise that an important element in business management practices is the need to successfully motivate and retain employees who survive organisational restructuring, downsizing, consolidation, reorganising or re-engineering initiatives. This paper examines the current human resource practices on the retention of core employees in twelve Australian organisations. It explores the relationship between human resource (HR) practices and retention and further identifies the elements of HR practices, which strongly influence the decision for core employees to stay. It is part of a three phased study and the methodologies discussed in this paper consist of a) a Delphi survey of expert opinions and $b$ ) an in-depth interview of HR Managers of organisations. Results from this study will assist in the development of an effective HRM retention program for organisations. Businesses can successfully keep critical employees with a total retention strategy and HR programs to support it.
\end{abstract}

\section{Introduction}

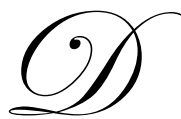

ue to the turbulent business environment, one of the challenges facing many business organisations today is the retention of critical employees. For many organisations, strategic staffing has become an important issue because their ability to hold on to their highly talented core employees can be crucial to their future survival (Clark 2001; Whitner 2001). Statistics show that while the annual turnover rate at established organisations is only $6 \%$, the cost of replacing an employee usually amounts to quarter of an individual's annual salary (Davies 2001).

Organisations today must wrestle with revolutionary trends: accelerating product and technological change, global competition, deregulation, demographic changes, and trends towards a service society and information age (Kane 2000). The workforce has changed dramatically in terms of age, gender, ethnic and racial composition, family structure, and job expectations. Consequently, such social developments have had significant impacts on the nature and operations of organisations (Ferris Hochwater, Buckley, Harrell-Cook Frink 1999; Kemske 1998) especially in the management of human resource. (e.g recruitment and selection, training and development and performance management programs) 
Several theoreticians have argued that the human resources of the company are potentially the only source of sustainable competitive edge for organisations (Becker \& Gerhart, 1996; Dyer, 1993; Ferris et al 1999; Pfeiffer, 1994; Wright \& McMahan, 1992). A human resource system helps create a workforce whose contributions are valuable, unique, and difficult for competitors to imitate (Pfeiffer 1998). A plethora of academic research conducted at the organisational level also suggests that human resource practices affect organisational outcomes by shaping employee behaviours and attitudes (Arthur, 1994; Huselid, 1995;Tsui, Pearce, Porter \& Tripoli, 1997).

Whitener (2001) indicates that employees interpret organisational actions such as human resource practices (Delery, 1998; Settoon et al., 1996; Ostroff and Bowen 2000; Wayne et al., 1997) and the trustworthiness of management (Eisenberger et al., 1990; Settoon et al., 1996) as indicative of the personified organisation's commitment to them. They reciprocate their perceptions accordingly in their own commitment to the organisation. A well-established stream of research rooted in social exchange theory has revealed that employees' commitment to the organisation derives from their perceptions of the employers' commitment to and support of them (Eisenberger et al., 1990; Hutchison \& Garstka, 1996; Settoon et al., 1996, Shore \& Tetrick, 1991; Shore \& Wayne, 1993; Wayne et al., 1997). In this regard, a useful framework in which to visualise commitment behaviour is to view them as components of fair exchange between a company and it employees. This approach to motivation postulates that employees and the organisations are involved in an exchange relationship (Pinder 1984).

Corporations must therefore strive to be the employer of choice by creating a positive environment, offering challenging assignments that foster continued personal growth. An employer of choice (EOC) is an organisation that outperforms its competition in the attraction, development and retention of people with businessrequired talent, often through innovative and compelling human resource programs (Desller 1999; Clarke 2001).

\section{Retention Management}

Effective retention management is a strategic, coherent process that starts with an examination of the reasons that employees join an organisation in the first place (Davies 2001; Fitz-enz 1990; Solomon 1999). An employee's decision to resign from a company is rarely due to a single event, such as being passed over for a promotion, a plum assignment or for monetary reasons. One such event may however serve as a catalyst, but most employees leave because of multiple factors - the turnover drivers - create an environment that is no longer desirable to them (Davies 2001; Walker 2001).

Hence, an organisation should determine the retention factors relevant to each of their employee category and then focus strategies on these factors. For each employee category, information can be gathered from current and former employees on their perceptions of why people stay or leave. The more focused the analysis, the more focused the prescriptive actions may be (Cavouras, 2000). Employee surveys can focus on commitment and retention factors. Exit interviews and follow-up surveys with former employees can be adapted to yield more accurate, useful information. Interviews, focus groups, and surveys among current employees provide perceptions of the relevant factors and their importance (Solomon 1999).

Organisations develop human resource policies that genuinely reflect their beliefs and principles about the relationship between management and employees or they may merely devise policies that deal with current problems or requirements. These practices include recruitment and selection, training and development, performance management, remuneration systems, occupational health and safety, industrial relations, HRIS, impact of recent legislation (EEO/AA/OHS/FOI etc. (Delery \& Doty 1996; Jackson \& Schuler 1995; Oakland \& Oakland 2000). It is however important to note that although the use of these practices increases the uniqueness and value of these crucial employees, it will also increase the costs associated with the loss of these highly talented core employees (Gutherie 2001).

\section{Core Employees}

Core employees are known as permanent workers, they have a full time position and they enjoy benefits such as pensions, health insurance, and vacations that are usually not available to temporary workers (Segal \& 
Sullivan, 1997). They carry out critical job functions with capabilities consisting of complex bundles of skills and collective learning, exercised through organisational processes that ensure superior coordination of functional activities (Allan \& Sienko 1997;Gramm \& Schnell 2001).

Researchers, Lepak and Snell (1999) further describe core employees of today's organisations as high value, high uniqueness employees whose skills and knowledge are a source of competitive value to the organisation. Their value and uniqueness may be based on 'tacit knowledge' that would be valuable to the competitor and these skills and knowledge are related to core processes developed internally and built up overtime (Entrekin \& Court 2001). Basically, a core employee is someone whose knowledge and performance contributes significantly to what their organisation does and what their organisation does better than their competitors.

A recent study (Chew 2003) examined the key characteristics of core employees in Australian organisations and the results indicated that all the descriptions seem to have a focus on knowledge, skills and attributes (KSA) that are of strategic value to the organisation. The description included the following five characteristics 1) possess knowledge, skills and attributes (KSA) aligned with business operation and direction, 2) is central to the productivity and wellbeing of the organisation 3) provide a competitive edge to the organisation, 4) support the organisational culture and vision and 5) possess skills, knowledge and abilities that are relatively rare or irreplaceable to ensure the success of the organisation.

\section{Human Resource Management Factors Influencing Retention}

Retention management is driven by the following factors, which should be managed congruently: organisational culture and structure, recruitment strategy, pay and benefits philosophy, employee support programs, and career development system (Fitz-enz 1990). Studies of progressive HRM practices in training, compensation and reward sharing have revealed that these can lead to reduced turnover and absenteeism, better quality work, and better financial performance (Arthur, 1994; Delaney \& Huselid, 1996; Huselid, 1995; Ichniowski, Shaw \& Prennushi, 1997; Snell \& Youndt, 1995; MacDuffie, 1995; Meyer \& Allan 1991; Solomon, 1992; Snell \& Dean, 1992).

Organisations are thus addressing a wide range of factors driving retention and commitment. Various frameworks or models are used (Beck 2001; Clarke 2001;Parker \& Wright 2001; Stein 2000), but such factors as the following are typically included:

\section{Selection}

The concept of person-job (P-J) fit emphasised matching people and jobs in terms of qualifications based on knowledge, skill, or ability, and overlooked other personal characteristics of applicants that might be more suitable for the assessment of "fit." (Edwards, 1991; Hall, 1930-31; Lofquist \& Dawis, 1969). However as the complexity of work increases, organisations now use more selection methods that capture the applicant's capability to do the work. Research on person-job fit has found that workers gravitate to jobs with complexity levels commensurate with their ability (Wilk, Desmarais, \& Sackett, 1995; Wilk \& Sackett, 1996). However, selection should also improve fit between the applicant and other aspects of the work (e.g. personality fit and organisation fit). For example, selection is used to improve fit between an applicant's values and the organisation culture (Cable \& Judge, 1997).

Person-organisation fit is considered in the context of personnel selection and can be based on the congruity between personal and organisation beliefs (Netemeyer et al., 1997; O'Reilly et al., 1991) or individual and company goals (Kristof, 1996; Vancouver et al., 1994). Lauver and Kristof-Brown found that both person-job fit and person-organisation fit predicted job satisfaction; however, person-organisation fit was a better predictor of intention to quit. Thus, people who are not well suited for the job and/or organisation are more likely to leave than those who have a good person-job or person-organisation fit. The organisation should not only match the job requirements with the person's knowledge, skills and abilities, but should also carefully match the person's personality and values with the organisation's values and culture. Holland (1985) espoused the theory that states an employee's satisfaction 
with a job, as well as propensity to leave that job, depend on the degree to which the individual's personality matches his or her occupational environment.

\section{Reward And Recognition Of Employee Value}

Employees tend to remain with the organisation when they feel their capabilities, efforts, and performance contributions are recognised and appreciated. A sense of accomplishment is important and a strong motivator. Compensation provides recognition, but other forms of non-monetary recognition are also important. Recognition from managers, team members, peers and customers enhance commitment (Walker 2001). Particularly important to the employees are opportunities to participate and to influence actions and decisions (Davies 2001; Gold 2001).

\section{Training And Career Development}

Employees are expected to acquire new skills and knowledge, apply them on the job, and share them with other employees (Noe, 1999). Training provides employees with specific skills or helps to correct deficiencies in their performance, while development is an effort to provide employees with abilities the organisation will need in the future (Gomez-Mejia, Balkin and Cardy, 1995; Wilk \& Cappelli, 2003). Skill development could include improving basic literacy, technological know-how, interpersonal communication, or problem solving abilities.

Increasingly, companies are strengthening development for talent, thorough competency analysis, input on individual interests, multi-source assessment of capabilities and development needs, and the formulation of action plans (Clarke 2001; Messmer 2000).

A 1999 Gallop poll named the lack of opportunities to learn and grow as a top reason for employee dissatisfaction. Kimko, Inc, took this information to heart and implemented a training program that gave employees a training path and career direction. Turnover tumbled from $75 \%$ to $50 \%$ (Withers 2001).

\section{Challenging Employment Assignment And Opportunities}

High talent individuals want work that is interesting, creative and challenging. They also expect work to be appropriately designed, with adequate resources available, and with effective management. Such an assignment broadens the employee's value to the company, while the necessity of mastering new skills keeps employees satisfied and creative (Ferguson, 1990; Walker 2001). Increasingly, companies are redesigning work, relationships, workflows, and teams to create more exciting and challenging work (Beck 2001; Stein 2000). Providing employees with challenging assignments with well-defined performance measures and feedback is important for a high performance environment in which employees can achieve their personal objectives (Boyer 1994).

A further extension of these efforts to provide job challenges is cross-functional career development. This technique allows the long-term employees which the organisation views as having overall leadership potential to move from one area of the company where they have succeeded (e.g., management) to another area where they have no experience (e.g., acquisitions). Moving high-calibre employees in this manner not only assures that they will be challenged, but begins to build employees with enough breadth of experience to assume senior leadership roles with the organisation. General Electric and IBM have been doing this for years (Ferguson, 1990).

\section{Equity Of Compensation And Benefits}

Wages influence the recruitment and retention of workers (e.g., Highhouse, Stierwalk, Bachiochi, Elder, \& Fisher, 1999; Rynes \& Barber, 1990; Williams \& Dreher, 1992) and therefore play a role in the staffing process. Companies often provide pay packages superior to the market for critical talent. These include special pay premiums, stock options, or bonuses. Base pay reflects fair pay; supplemental programs reflect individual, team, or organisational performance and success (Jones et al., 2001; Parker \& Wright 2001). Innovative practices reflect the individual player contract model, focusing on "what it will take" to attract and retain each individual, regardless of the pay of others. This "let's make a deal" approach is a radical departure from traditional pay equity approaches, 
but seems to work in a highly competitive, individualised talent market. Others act more broadly, ensuring that all "players" are paid near the top of the market, whether through base salary or bonuses (Stein 2000; Williams 1999). This raises overall compensation costs but may reduce the risk, and therefore the cost, of attrition.

\section{Organisational Factors Influencing Retention}

\subsection{Leadership}

Leadership is defined as the behaviour of an individual that results in non-coercive influence when that person is directing and coordinating the activities of a group toward the accomplishment of a shared goal (Bryman 1992) Research findings suggest that leadership enhances organisation commitment (Allen 1995; Bykio Hacket Peterson 1994; Ferres, Travaglione and Connell 2002; Podsekoff, Mackenzie \& Bommer 1996).

Studies indicate transformational leadership would be more highly related to employees' perceived satisfaction and effectiveness than transactional leadership (Yammarino and Bass, 1990). Studies have found high levels of peak performance under transformational leadership (Stoner-Zemel, 1988), high correlation between charismatic leadership and effectiveness (Bass and Avolio 1995; Seltzer and Bass, 1987) and Yammariono \& Bass (1990) found positive influence of transformation leaders in organisational outcomes which resulted in lowered intention to leave and increased organisational citizenship behaviour.

\subsection{Company Culture And Structure (Policies)}

Corporate culture is described as the invisible forces that shape life in a business organisation (Fitz-enz 1990; Sheriden 1992). Management philosophy and style, communications protocol and policies, rituals and taboos interact to create the uniqueness of each company. People often join a company or seek employment within a particular industry because they find its culture appealing. However, in the past decade the cultural characteristics of some industries and, therefore, the companies within them have changed markedly. And when the culture changes, whether through growth, new management, or economic and regulatory interventions, some people become uncomfortable and leave to find a culture that fits them better (Stum 1998).

The complement of culture is structure, which is shaped by culture and technology. Structure starts with job design and workflow patterns, and includes policies and procedures, spans of control, reporting relationships, and other factors that dictate how work is to be done and business conducted. Both IBM and Apple Computer Inc., for example, make and sell computing equipment. Yet, it would be difficult to find two companies with more disparate cultures or structures.

Since people join organisations partly because they are attracted to the culture and structure, this is where retention management begins. Managers who want to examine how effective their corporate culture and structure are at retaining employees need to do so from the ground up (Sheriden 1992; Stum 1998).

\subsection{Communication And Consultation}

Effective communications strengthen employee identification with the company and build trust. Increasingly, companies provide information on values, mission, strategies, competitive performance, and changes that may affect employees (Clarke, 2001; Levine, D.1995). Many companies are working to provide information employees want and need, through the most credible sources (eg. CEO for strategies and first-line managers for work issues) on a timely and consistent basis. New paradigm companies recognise that external business strategies require counterparts for human resources often involving significantly changed roles for the HR function. In these companies, people are acknowledged as human resources and are not seen merely as cost accounting liabilities. Their contribution is seen as the corporate second bottom line. There is communication and there is trust, and these factors are reciprocal. These are the basic elements underlying employer-employee relationships that enact a new "psychological contract" between the two (Bozeman \& Perrewe 2001; Meyer \& Allan 1993). 


\subsection{Effective Integration: Working Relationships}

Employees stay when they have strong relationships with others they work with (Clarke 2001). Companies encourage team building, project assignments involving work with peers, and opportunities for social interaction both on and off the job (Johns et al 2001). One value of team-based organisations is the bond they establish among members. Effective relationships with immediate managers are also important. Companies are also using survey measures and management feedback to identify ways to improve relationships and the context of work

\subsection{Satisfactory Working Environment}

The factor most significantly affecting workforce commitment is management's recognition of the importance of personal and family life (Stum 1998). For some employees, personal priorities or circumstances make the difference between leaving and staying. Individuals will stay with a company that clearly considers and cares for their career priorities (life stage needs), health, location, and family, dual-career, other personal needs (Gonyea \& Googins, 1992; Kamerman \& Kahn, 1987). For example, many companies are providing flexible schedules and work arrangements and are experimenting with other ways to help individuals manage their work and personal life issues (Perry-Smith \& Blum 2000; Solomon 1999).

Through such practices outlined, companies are striving to improve employee retention. Why then, do employees continue to leave?

Several studies suggest that high-involvement work practices will enhance employee retention (Arthur, 1994; Huselid, 1995; Koch \& McGrath, 1996). Although there has been substantial literature on HRM "best practices and high performance practices", there is however, little consensus among researchers with regard to precisely which HRM practices should be included as the "ideal type" of HRM system that is universally effective. Given these different approaches to HRM, it is evident that a more consolidated field of investigation would be beneficial to the development of knowledge in this area.

Reviewing the current HRM literature, there is to date no study of large Australian organisations with regards to their HR practices on retention. It raises unexplored issues. Questions such as, Which HR factors most, influence the decision of employees to stay? How do these practitioners perceive their effectiveness? More specifically, if there is indeed an impact of HRM systems on retention of employees, how do these effects occur? What are the mechanisms through which these effects manifest themselves? Do these effects vary under different levels of contextual or environmental factors? These questions call for theory refinement and the development of more comprehensive theoretical models of the HRM-retention relationship.

In order to provide better insights into the process and practices that companies utilise to retain their employees, three key research questions were formulated to guide this research.

\section{Phase 1-Delphi Technique}

1. Which HR factors most influence the decision of employees to stay?

\section{Phase 2 - Interview}

2. Is there a relationship between the identified HRM factors and retention rates in organisations?

3. How are these influential HR factors managed in organisations? 


\section{Research Methodology}

\subsection{Phase 1 - Delphi Technique}

In this study, the Delphi technique was selected as an intermediate methodology, to conduct a preliminary investigation to explore the relationship between HR practices and retention and further identify the elements of HR practices, which strongly influence the decision for core employees to stay. The Delphi method has been shown to be an effective way to conduct research when the responses being sought are value judgments rather than factual information (Dalkey and Rourke 1972). Linstone and Turoff (1975) also agree that Delphi is particularly useful for studies that call for subjective judgment rather than precise statistical analysis.

\subsubsection{Panellist}

The panellists used for this study were all experienced practitioners and academics. All were associated with human resources management, researching, teaching or policy development. Many had contributed to the existing literature on management. The panellists' knowledge of the subject matter at hand is the most significant assurance of a quality outcome, and so participants were chosen because of their expertise related to the subject (Stone Fish \& Busby, 1996).

A total of 20 nominees consisting of senior academics, HR practitioners and industrial psychologists were contacted through postal mail. The nature of the study was explained and they were invited to participate. Thirteen experts accepted. The panel size of thirteen fits within the guidelines recommended for Delphi studies (Helmer 1983; Turoff 1975). The demographic data of the panel were reported in Table 1.

Table 1: Demographic Characteristics Of The Delphi Panel Members

\begin{tabular}{|l|c|c|}
\hline \multicolumn{1}{|c|}{ Characteristic } & Number & Percentage \\
\hline Invited Participants & 20 & 100 \\
\hline Accepted Participants & 13 & 66 \\
\hline Age & \multicolumn{2}{|l|}{} \\
\hline $30-40$ & 2 & 15.38 \\
\hline $41-50$ & 4 & 30.77 \\
\hline $51-60$ & 4 & 30.77 \\
\hline $61-70$ & 3 & 23.08 \\
\hline Gender & 10 & 76.92 \\
\hline Male & 3 & 23.08 \\
\hline Female & 9 & 69.23 \\
\hline Highest Qualifications & 1 & 7.69 \\
\hline PhD & 1 & 7.69 \\
\hline DBA & 1 & 7.69 \\
\hline MBA & 1 & 7.69 \\
\hline MHRM & \multicolumn{2}{|l|}{} \\
\hline M.Psych. & 6 & 46.15 \\
\hline Occupation & 4 & 30.77 \\
\hline Senior Academics & 3 & 23.08 \\
\hline HR Practitioners &
\end{tabular}

\subsubsection{Application Of The Delphi Technique}

Three rounds of questionnaires were mailed to the panel of experts. The first round consisted of a relatively open-ended set of questions used to identify 1) human resource management factors that influence retention of core employees and 2) organisational factors that influence retention of core employees. Responses to the open-ended 
question in the first round were analysed qualitatively and categorised or grouped by frequency or similarity of response in order to reduce the number to a manageable level but yet keeping the essential meaning of the responses. The results were then grouped together under a limited number of headings and statements (eg. human resource management factors and organisational factors) and this was then drafted for circulation to all participants in a second questionnaire. The second round used questions developed from responses to the first questionnaire. The participants were asked to rank each statement on a 1 to 5 scale (1 being the most important) and to optionally comment on each question. Responses to second round were analysed to determine the ranking of the items. Ranking votes (1-5) assigned to items by participants in questionnaires 2 were tallied. In the final round, participants re-ranked their agreement with each statement in the questionnaire, with the opportunity to change their scores in view of the group's responses. The re-ranking's were summarised and assessed for the degree of consensus. This resulted in the selection of a) five key elements that affect retention and b) five key organisational factors that affect retention.

\subsubsection{Phase 1 - Delphi Technique Results}

\section{Which HR factors most influence the decision of employees to stay?}

Table 2 reports the panel's selection of the top five human resource management factors influencing retention. In order of importance, they included effective selection, reward and recognition, training and career development, challenging employment structures and opportunities and equity of compensation and benefits.

Panellist (3) noted that pay is critical for employees. I also think however that level of responsibility and ability to utilise and develop skills are key features that attract individuals to jobs. Again however, I feel that there are many different factors ie sex, age, social status etc that will influence the types of HR factors that are important.

One of the panellist's (2) highlighted that expectation and needs of employees differ at different stages. Younger people are linked to remuneration, training and development, challenging job, growth opportunities, trying new things, fitting the job properties to their educational training, recognition of their capabilities and acquisition of new skills. As for older employees: salary is not important, career advancement not so important. How can I enrich my job? How can I make this place something better? The focus is on autonomy, liberty from mundane things, mentoring of other organisational people to make greater contribution to the organisation. There is interest in crisis management in lieu of repetitive job. Security in tenure is particularly important for older workers, as they are less likely to move to a new organisation and risk redundancy (Panellist 5).

Another panellist stated that in terms of influencing retention positively his organisation focuses on strategic human resources - ensuring there is a link between our functional responsibilities and our business strategy. The aim is to demonstrate a commitment for employees ensuring we enhance our employee's capabilities and receive a benefit through employment. Focus would obviously be on developing a positive working environment through leadership style, terms and conditions of employment, availability and allocation of resources, communication and consultation, reward and recognition, training and development (Panellist 8).

Table 2: Top Five Human Resource Factors Influencing Retention

\begin{tabular}{||l|l||}
\hline \multicolumn{1}{|c|}{ RANK } & $\begin{array}{c}\text { PANEL SELECTION OF TOP FIVE } \\
\text { HUMAN RESOURCE MANAGEMENT FACTORS }\end{array}$ \\
\hline 1. & Effective Selection. \\
\hline 2. & Reward and recognition of employee value. \\
\hline 3. & Training and Career Development. \\
\hline 4. & Challenging Employment Structures and Opportunities \\
\hline 5. & Equity of compensation and benefits. \\
\hline
\end{tabular}




\section{Moderating factors -Organisational factors influencing retention}

Table 3 lists the panel's selection of the top five organisational factors that influence retention. In order of importance they include influential and sensitive leadership style, company policies and culture, communication and consultation, effective integration working relationships and satisfactory working environment.

Several panellists $(4,7,8)$ indicated that employees would remain in an organisation due to a satisfying working environment: suitable work conditions and good workmates provide comfort and security needed to support work activity. A quality of working life that allows sufficient monetary reward to meet individuals' needs, challenging work and a workload that allows balance for individuals' lifestyle needs to be met.

Leadership management according to panellists 4 and 5 relates to sound supervision and direction: clear work objectives/standards, good instructions on how to do the job, objective performance assessment and an influential and sensitive leadership style from supervisor/manager provides an understandable and acceptable context in which to get jobs done as required.

Two panellists $(8,10)$ echoed similar ideas. They felt that clearly defined company policies and culture play an essential role in allowing employees to know that they fit in. Communication: Quality and timeliness of feedback to employee - appropriate and timely feedback is the hallmark of an effective organisation.

Table 3: Top Five Organisational Factors influencing retention

\begin{tabular}{||r|l|l||}
\hline \hline RANK & $\begin{array}{l}\text { PANEL SELECTION OF TOP FIVE } \\
\text { ORGANISATIONAL FACTORS }\end{array}$ & \\
\hline 1. & Influential and sensitive leadership style. & \\
\hline 2. & Company policies and culture. & \\
\hline 3. & Communication and consultation. & \\
\hline 4. & Effective integration: working relationships. & \\
\hline 5. & Satisfactory working environment. & \\
\hline
\end{tabular}

\subsection{Phase 2 - In-Depth Interviews}

This method involved the interviewing of human resource managers or representatives of twelve Australian organisations based in Western Australia, using a semi -structured interview questionnaire, which incorporated a list of HRM factors (identified from Phase 1) affecting retention of critical employees. A tape recorder was used during the interview (with the permission of the participants) for the purpose of later transcribing the responses.

The objective of Phase 2 of this research was to investigate the current retention management practices of Australian organisations and further examine the level of importance these organisations placed on the identified HRM factors.

Table 4 provides a profile of the twelve organisations used in this study. The participating organisations were from various industry sectors and they included health-care, higher education, public sector, diversified industries and manufacturing. The interviewed organisations were deemed to be large, with the number of employees over 3000. Two-thirds (8) of the participating organisations had in their employment more than $50 \%$ of core (critical) employees. 
Table 4: Demographic Characteristics Of Participating Organisations

\begin{tabular}{|c|c|c|c|}
\hline $\begin{array}{l}\text { Type Of } \\
\text { Industry }\end{array}$ & $\begin{array}{c}\text { Number Of } \\
\text { Organisations }\end{array}$ & $\begin{array}{l}\text { Size Of Organisation } \\
\text { (No Of Employees) }\end{array}$ & $\begin{array}{c}\text { Number Of } \\
\text { Core Employees }\end{array}$ \\
\hline Health care & 3 & $>10,000$ & $\begin{array}{ll}\text { Less } 50 \% & (1) \\
\text { Greater } 50 \% & (2) \\
\end{array}$ \\
\hline Higher Education & 3 & $\begin{array}{l}<3000 \\
>10000\end{array}$ & $\begin{array}{ll}\text { Less } 50 \% \\
50 \%\end{array}$ \\
\hline Public Sector & 3 & $\begin{array}{l}<3000 \\
>10000\end{array}$ & $\begin{array}{ll}\text { Less } 50 \% & (1) \\
\text { Greater } 50 \% & (2) \\
\end{array}$ \\
\hline $\begin{array}{l}\text { Diversified } \\
\text { Industries }\end{array}$ & 2 & $\begin{array}{l}<1000 \\
>10000\end{array}$ & $\begin{array}{l}\text { Less } 50 \% \\
50 \%\end{array}$ \\
\hline Manufacturer & 1 & $>100000$ & Less $50 \%$ \\
\hline
\end{tabular}

*Numbers in brackets ( ) denote the number of organisations.

\subsubsection{Phase 2 - Interview Results}

The results of the interviews of the 12 respondents were reported in two ways. First the categorical responses provided by the interviewees are presented in Table 5 and Table 6 to enable an understanding of the key trends evident. This information is then further explored using interview comments provided by participants.

Respondents were asked to rate the ten identified factors from Phase 1 , using the scale, $0=$ somewhat important, $1=$ important and $2=$ very important. The scores from each factor were aggregated and the identified elements ranked accordingly. Table 5 illustrates the responses of the interviewees regarding the level of importance their organisations placed on the identified human resource management and organisational factors in relation to the retention management of their core employees.

\section{Is there a relationship between the identified HRM factors and retention rates in organisations?}

Results depicted in Table 5 indicate the level of importance interviewees placed on a) the identified human resource management factors and $b$ ) the identified organisational factors in relation to retention of their core employees:

The human resource management factors assessed by the interviewees in order of importance included the following: 1) effective selection, 2) challenging employment assignments and opportunities and 3) training and career development, 4) reward recognition of employee value and 5) equity compensation.

The organisational factors assessed by the interviewees in order of importance included the following: 1) leadership 2) company policies and culture, 6) communication and consultation, effective integration: working relationships, 8) satisfying working environment

It is significant to note that with regards to the level of importance of organisational factors influencing retention, the interviewees (Phase 2) preferences matched that of the panellists rank in Phase 1 (see Table 3). However, in terms of the level of importance of the human resource management factors, there is a slight difference in order of preference. The panellists (Phase 1) considered reward and recognition as the second most important factor after effective selection but the interviewees (Phase 2) ranked it as the fourth most important. The interviewees selected challenging assignments and opportunities as the second most important factor ahead of training and career development whilst the panellists ranked training and career development as more important than challenging assignments and opportunities.

It was commented by several of the interviewees $(8,911,12)$, in the public sector, pay is not an issue more the motivation and deployment. Training, job challenges and work environment especially work relationships, team work and shared camaraderie is important. Interviewee 10 noted that with regards to career changes and challenging 
jobs- people are seeing more career changes, Generation X are starting to impact - career changes- we are seeing people interested in moving laterally rather than upward. We see society generally putting greater emphasis on work life balance (Interviewees 4,5,6,9,10).

Table 5: Level Of Importance Of Identified Human Resource And Organisational Factors In Relation To Retention Management

\begin{tabular}{|c|c|c|c|c|c|c|c|c|c|c|c|c|c|c|}
\hline \multicolumn{15}{|c|}{ Scale: $0=$ =Somewhat Important 1 =Important 2 = Very Important } \\
\hline \multicolumn{15}{|c|}{ Organisations } \\
\hline HRM Factors & C1 & $\mathbf{C 2}$ & $\mathbf{C 3}$ & C4 & C5 & C6 & C7 & C8 & C9 & C10 & C11 & C12 & $\begin{array}{c}\text { Level of } \\
\text { Importance } \\
\text { Individual } \\
\text { Factor }\end{array}$ & \\
\hline 1. Effective Selection & 2 & 2 & 1 & 2 & 2 & 2 & 1 & 2 & 1 & 2 & 2 & 2 & $21 \quad(\mathbf{1})$ & 1) \\
\hline $\begin{array}{l}\text { 2. Reward and recognition } \\
\text { of employee value }\end{array}$ & 0 & 2 & 2 & 2 & 0 & 2 & 1 & 1 & 1 & 2 & 1 & 0 & 14 & 4) \\
\hline $\begin{array}{l}\text { 3. Training and Career } \\
\text { Development }\end{array}$ & 0 & 2 & 2 & 1 & 2 & 2 & 2 & 2 & 2 & 1 & 1 & 1 & 18 & 3) \\
\hline $\begin{array}{l}\text { 4. Challenging employment } \\
\text { assignments and } \\
\text { opportunities }\end{array}$ & 2 & 2 & 2 & 2 & 2 & 2 & 1 & 2 & 2 & 1 & 0 & 1 & 19 & 2) \\
\hline $\begin{array}{l}\text { 5. Equity of compensation } \\
\text { and benefits }\end{array}$ & 2 & 0 & 2 & 1 & 1 & 1 & 0 & 1 & 0 & 0 & 0 & 0 & (5) & \\
\hline \multicolumn{15}{|l|}{ Organisational Factors } \\
\hline $\begin{array}{l}\text { 6. Influential and sensitive } \\
\text { leadership style }\end{array}$ & 1 & 2 & 2 & 2 & 2 & 2 & 2 & 2 & 2 & 2 & 2 & 2 & 23 & \\
\hline $\begin{array}{l}\text { 7. Company policies and } \\
\text { culture }\end{array}$ & 0 & 2 & 2 & 2 & 2 & 2 & 2 & 2 & 1 & 0 & 1 & 1 & 17 & \\
\hline $\begin{array}{l}\text { 8. Communication and } \\
\text { consultation }\end{array}$ & 2 & 0 & 2 & 2 & 1 & 2 & 1 & 1 & 2 & 0 & 0 & 2 & 15 & \\
\hline $\begin{array}{l}\text { 9. Effective integration: } \\
\text { working relationships }\end{array}$ & 1 & 2 & 2 & 1 & 1 & 1 & 1 & 1 & 2 & 2 & 0 & 0 & 14 & \\
\hline $\begin{array}{l}\text { 10.Satisfactory working } \\
\text { environment }\end{array}$ & 0 & 2 & 2 & 1 & 1 & 1 & 1 & 1 & 1 & 1 & 0 & 1 & 12 & \\
\hline $\begin{array}{l}\text { Level of Importance of } \\
\text { Aggregated Factors }\end{array}$ & 10 & 16 & 20 & 16 & 15 & 17 & 12 & 13 & 14 & 11 & 7 & 8 & & \\
\hline Voluntary Turnover rate (\%) & $21 \%$ & $\begin{array}{c}\text { Up } \\
\text { to } \\
10 \%\end{array}$ & $\begin{array}{l}\text { Up } \\
\text { to } \\
10 \%\end{array}$ & $6 \%$ & $\begin{array}{c}\text { Up } \\
\text { to } \\
10 \%\end{array}$ & $10 \%$ & $12 \%$ & $10 \%$ & $6 \%$ & $13 \%$ & $\begin{array}{l}11 \% \\
\text { to } \\
20 \%\end{array}$ & $\begin{array}{l}\text { Less } \\
\text { than } \\
10 \%\end{array}$ & & \\
\hline
\end{tabular}

\section{How are these influential HR factors managed in organisations?}

Table 6, reports the responses provided by participants pertaining to the effective management of the identified human resource management and organisational factors in their organisation. The responses were categorised as good or poor.

Results shown in Table 6, indicates that organisations with high voluntary turnover $11 \%-21 \%$ (C1, C7, $\mathrm{C} 10, \mathrm{C} 11)$ have a lower aggregated score $(5,5,5,5,3)$ of effective management of identified human resource management and organisational factors. Organisations with lower voluntary turnover 6\%-10\% (C2, C3, C4, C5, C6, $\mathrm{C} 8$, and $\mathrm{C} 12$ ) have a higher aggregated score of effective management of identified factors. 
Table 6: The Effective Management Of Identified HRM Factors And Organisational Factors In Organisations

\begin{tabular}{|c|c|c|c|c|c|c|c|c|c|c|c|c|}
\hline Good 6 Poor & \multicolumn{12}{|c|}{ Organisations } \\
\hline HRM Factors & C1 & $\mathrm{C2}$ & C3 & $\mathrm{C4}$ & C5 & C6 & C7 & C8 & C9 & $\mathbf{C 1 0}$ & C11 & $\mathrm{C12}$ \\
\hline 1.Effective Selection & 4 & 4 & 4 & 4 & 4 & 4 & 4 & 4 & 4 & 4 & 4 & 4 \\
\hline $\begin{array}{l}\text { 2.Reward and recognition of } \\
\text { employee value }\end{array}$ & 6 & 4 & 4 & 4 & 6 & 4 & 6 & 6 & 4 & 4 & 6 & 6 \\
\hline $\begin{array}{l}\text { 3.Training and Career } \\
\text { Development }\end{array}$ & 6 & 4 & 4 & 6 & 4 & 4 & 4 & 4 & 4 & 6 & 6 & 4 \\
\hline $\begin{array}{l}\text { 4.Challenging employment } \\
\text { assignments and opportunities }\end{array}$ & 4 & 4 & 4 & 4 & 4 & 4 & 4 & 4 & 4 & 6 & 4 & 4 \\
\hline $\begin{array}{l}\text { 5.Equity of compensation and } \\
\text { benefits }\end{array}$ & 4 & 4 & 6 & 6 & 4 & 6 & 6 & 6 & 4 & 6 & 6 & 4 \\
\hline Organisational Factors & & & & & & & & & & & & \\
\hline $\begin{array}{l}\text { 6. Influential and sensitive } \\
\text { leadership style }\end{array}$ & 6 & 4 & 4 & 4 & 4 & 4 & 6 & 4 & 6 & 4 & 6 & 4 \\
\hline $\begin{array}{l}\text { 7. Company policies and } \\
\text { culture }\end{array}$ & 6 & 4 & 4 & 4 & 4 & 4 & 6 & 4 & 4 & 6 & 6 & 6 \\
\hline $\begin{array}{l}\text { 8. Communication and } \\
\text { consultation }\end{array}$ & 4 & 6 & 4 & 4 & 6 & 4 & 6 & 6 & 6 & 6 & 6 & 4 \\
\hline $\begin{array}{l}\text { 9. Effective integration: } \\
\text { working relationships }\end{array}$ & 4 & 4 & 4 & 4 & 4 & 6 & 4 & 4 & 4 & 4 & 6 & 6 \\
\hline $\begin{array}{l}\text { 10. Satisfactory working } \\
\text { environment }\end{array}$ & 6 & 4 & 4 & 4 & 4 & 6 & 4 & 4 & 4 & 4 & 4 & 4 \\
\hline $\begin{array}{l}* \text { Effective management } \\
\text { (Aggregated score out of } 10)\end{array}$ & 5 & 9 & 9 & 8 & 8 & 7 & 5 & 7 & 8 & 5 & 3 & 7 \\
\hline Voluntary Turnover rate $(\%)$ & $21 \%$ & $\begin{array}{l}\mathrm{Up} \\
\text { to } \\
10 \%\end{array}$ & $\begin{array}{l}\mathrm{Up} \\
\text { to } \\
10 \%\end{array}$ & $6 \%$ & $\begin{array}{l}\text { Up } \\
\text { to } \\
10 \%\end{array}$ & $10 \%$ & $12 \%$ & $10 \%$ & $6 \%$ & $13 \%$ & $\begin{array}{l}11 \% \\
\text { to } \\
20 \%\end{array}$ & $\begin{array}{l}\text { Less } \\
10 \%\end{array}$ \\
\hline
\end{tabular}

It was pointed out by one of the respondents (Interviewee 9) that HR department in this organisation is still viewed as a process department rather than being involved in planning the strategic effort. Interviewee (1) stated quite categorically that her organisation does not have a problem attracting employees but we have a retention problem. We do not believe that managing human resource is a competitive advantage and therefore treat our people as tools. We need to treat our core employees better. It is costing us money.

According to interviewee (10), her organisation's succession planning - mixed feelings - like to use the word contingency planning and multi-skilled. Succession planning in theory is fantastic but not an ideal model. Not just identifying key people but provide more training to allow people to step into that role. We like to test the market at that level. It does not mean that we do not train people but I think if this people are so valuable to the organisation we owe it to our shareholders to adopt strategy to rope this people in. For our employees at a lower level but key people significant to the organisation we address it through multi-skill.

With regards to performance appraisal, several interviewees $(4,8,10)$ noted that it was time consuming, very few organisations do it well. We do have a performance appraisal system here that is linked to our training needs- the timing of it can be improved (10).

\section{The Perceived Level Of Importance Of The Identified HRM Factors And Their Effective Management}

Table 7 shows the relationship between the organisations' perceived level of importance of the identified HRM factors and their effective management of these factors. Results revealed that seven organisations (C2, C3, C4, C5, C6, C8, C9) with a high aggregated score of the level of importance displayed effective management of these practices and consequently had low voluntary turnover. Conversely, four organisations $(\mathrm{C} 1, \mathrm{C} 7, \mathrm{C} 10, \mathrm{C} 11)$ with low aggregated score of the level of importance exhibited low effective management of the identified practices and consequently high voluntary turnover. 
Table 7: The Relationship Between The Level Of Importance And The Effective Management Of The Identified HRM Factors

\begin{tabular}{|c|c|c|c|c|c|c|c|c|c|c|c|c|}
\hline Organisations & C1 & $\mathrm{C2}$ & $\mathbf{C 3}$ & $\mathrm{C4}$ & C5 & C6 & C7 & C8 & C9 & C10 & C11 & $\mathbf{C 1 2}$ \\
\hline $\begin{array}{l}\text { * Level of Importance } \\
\text { (Aggregated score) }\end{array}$ & 10 & 16 & 20 & 16 & 15 & 17 & 12 & 13 & 14 & 11 & 7 & 8 \\
\hline $\begin{array}{l}* * \text { Effective management } \\
\text { (Aggregated score out of } 10 \text { ) }\end{array}$ & 5 & 9 & 9 & 8 & 8 & 7 & 5 & 7 & 8 & 5 & 3 & 7 \\
\hline Voluntary Turnover rate $(\%)$ & $21 \%$ & $\begin{array}{l}\text { Up to } \\
10 \%\end{array}$ & $\begin{array}{l}\text { Up to } \\
10 \%\end{array}$ & $6 \%$ & $\begin{array}{l}\text { Up to } \\
10 \%\end{array}$ & $10 \%$ & $12 \%$ & $10 \%$ & $6 \%$ & $13 \%$ & $\begin{array}{c}11 \% \\
\text { to } \\
20 \%\end{array}$ & $\begin{array}{l}\text { Less } \\
10 \%\end{array}$ \\
\hline
\end{tabular}

* Level of importance of HRM factors - Higher aggregated score indicates organisations' rating of higher level of importance of HRM factors influencing retention

** Effective Management - Higher aggregated score indicates higher effective management of identified factors.

\section{Discussion And Implications}

HR is often assigned the role of steward of the corporate culture, expected to contribute to its development through programs and policies that enhance it (Ulrich, 1996). There is considerable debate in the HRM literature about the importance of aligning HRM practices with company strategy. For organisations, retaining their valued core employees is considered a strategic issue and a competitive business advantage (Clarke 2001; Hom \& Griffeth 1995; Huselid 1995). Successful organisations share a fundamental philosophy to value and invest in their employees (eg. Kotter \& Heskett, 1992; Maguire, 1995).

The nature of work is changing in Australia, as is the nature of workers themselves. Becker (1996) theorised that over time an employee invests in an organisation (eg. pensions, pay raises, benefits, stock, position, etc.), and these investments bond the individual to the organisation. Since these investments, increase with age and tenure, an employee tends to become more committed to the employing organisation, and the bond reduces the likelihood that the employee will quit (Meyer \& Allen, 1993; Wallace, 1997).

Existing studies support the contention that worker preferences for job and organisational characteristics are related to job performance, voluntary termination, and employee affective commitment to both the job and the organisation (eg Calwell \& O'Reilly, 1990; O'Reilly, Chapman, \& Calwell, 1991). Results of this study verify that organisations that manage their human resource effectively have higher retention of their employees (see Table 6). Moreover, results (Table 7) indicate organisations that placed greater importance on the identified HRM factors show a higher level of effective management.

The findings of this research provide relatively strong support for the existence of a positive relationship between HRM practices and its influence on the retention of core employees of organisations. More specifically, the research does identify the relevant human resource management factors that influence core employee's decision to stay with an organisation. It further identifies current human management practices of Australian organisations with regards to their retention program.

From a theoretical viewpoint, it could be argued that these findings about current human management practices in these organisations are hardly surprising, since the management literature is strewn with examples of the benefits of continuous improvement in HRM. None the less, from a practical viewpoint, the real value of the findings reported here is twofold. Firstly, the findings encourage the spread of good practice by fleshing out, in some detail, the retention management activities that are currently being used to good effect in some organisations. Secondly, the research findings described in this paper present a compelling argument for the real value of putting management theory into practice. 


\section{Future Research}

While this study makes a valid contribution to our understanding of the relationship between HRM and retention, this study is clearly only a first step and additional research is needed on this issue. Further empirical investigations, testing the dynamics of the HRM-retention effectiveness link is recommended. More definitive empirical validation of the "hows" and "whys" of this relationship might also prove to be the most convincing evidence to practitioners of the value of a strategic retention management tool.

\section{References}

1. Allan, P \& Sienko, S (1997), “A comparison of contingent and core workers' perceptions of their jobs' characteristics and motivational properties", SAM Advanced Management Journal, summer, v62 n3 p4 (7).

2. Allen, M. W. (1992). Communication and organisational commitment: perceived organisational support as a mediating factor", Communication Quarterly, 40, 357-367.

3. Arthur, J. (1994), "Effects of human resource systems on manufacturing performance and turnover", Academy of Management Journal, 37: 670-687.

4. Bass, B.M \& Avolio, B.J 1995, The Multifactor Leadership Questionnaire, Mind Garden, Paolo Alto, CA.

5. Beck, S, (2001), "Why Associates Leave, and Strategies To Keep Them", American Lawyer Media L.P.

6. Becker, B., \& Gerhart, B. (1996), "The impact of human resource management on organisational performance: Progress and prospects", Academy of Management Journal, 39: 779-801.

7. Bozeman, D.B \& Perrewe, P.L (2001), "The Effect of Item Content Overlap on Organisational Commitment Questionnaire--Turnover Cognitions Relationships", Journal of Applied Psychology Feb, v86 i1 p16.

8. Bryman, A (1992), Charisma \& leadership in organisations, Sage Publications, Newbury, C.A.

9. Cable D, Judge T (1997). "Interviewers' perceptions of person-organisation fit and organisational selection decisions", Journal of Applied Psychology, 82,546-561.

10. Caldwell, D. F. \& O'Reilly, C. A. (1990). "Measuring person-job fit with a profile-comparison process", Journal of Applied Psychology, 75: 648-657.

11. Cavouras, C.A. (2000), "Retention factors", Las Vegas, NV. Lawrenz Consulting Workshop.

12. Chew, J (2003), "Defining Core Employees: An Exploration of Human Resource Architecture", ANZAM conference, Fremantle, Western Australia.

13. Clarke, K.F (2001), "What businesses are doing to attract and retain employees--becoming an employer of choice", Employee Benefits Journal, Mar, Brookfield.

14. Davies, R, (2001), “ How to boost Staff Retention”, People Management, April 19, v7, i8, pp 54 (2).

15. Delery, J. E. (1998). "Issues of fit in strategic human resource management: implications for research", Human Resource Management Review, 8, 289-309.

16. Delery, J. E., \& Doty, D. H. 1996. "Theoretical frameworks in strategic human resource management: Universalistic, contingency and configurational perspectives", Academy of Management Journal, 39: 802-835.

17. Desller, G, (1999), "How to earn your employees' commitment", The Academy of Management Executive, May, v13 i2 p58 (1).

18. Delaney, J. T., \& Huselid, M. A. (1996). "The impact of human resource management practices on perceptions of organisational performance", Academy of Management Journal, 39, 949-969.

19. Edwards, J. R. (1991). "Person-job fit: A conceptual integration, literature review, and methodological critique". In C. L. Cooper \& I. T. Robertson (Eds.), International Review of Industrial and Organisational Psychology (Vol. 6, pp. 283-357): John Wiley \& Sons Ltd.

20. Eisenberger, R., Fasolo, P., \& Davis-LaMastro, V. (1990). "Perceived organisational support and employee diligence, commitment, and innovation", Journal of Applied Psychology, 75, 51-59.

21. Entrekin, L \& Court, M (2001), "Human Resource Management Practices: An Analysis of Adaptation and Change in an Age of Globalisation", International Labour Office working paper 2.

22. Ferris, G.F; Hochwarter, W.A; Buckley, R.M; Harrell-Cook, G; Frink, D.D (1999), "Human resources management: some new directions", Journal of Management, May-June v25 i3 p385 (3).

23. Fitz-enz, J (1990), “Getting - and keeping - good employees", Personnel, August: v67 n8 p25 (4). 
24. Ferguson. W (1990), "Creative compensation: keeping employees on board", Journal of Property Management, May-June; v55 n3 p12 (4).

25. Gold, M, (2001), "Breaking all the rules for recruitment and retention", Journal of Career Planning and Employment, Spring v61, i3, p6.

26. Gomez-Mejia, L. R., Balkin, D. B., Cardy, R. L. (1995). Managing Human Resources. Englewood Cliffs, NJ: Prentice-Hall, Inc.

27. Gonyea, J.G, \& Googins, B.K, 1992, "Linking the worlds of work and family: Beyond the productivity trap", Human Resource Management, 31: 209-211.

28. Gramm, C.L \& Schnell, J.F (2001), "The Use of Flexible staffing arrangements in core production jobs", Industrial and Labor Relations Review, Jan, v54 i2 p245.

29. Gutherie, J.P (2001), "High involvement work practices, turnover and productivity: Evidence from New Zealand", Academy of Management Journal, Feb, v44 i1 p180.

30. Highhouse, S, Stierwalt, S.L, Bachiochi, P, Elder, A.E and Fisher, G, (1999), "Effects of advertised human resource management practices on attraction of African American applicants", Personnel Psychology, Summer, v52 i2 p 425(1).

31. Huselid, M. A. (1995). "The impact of human resource management practices on turnover, productivity, and corporate financial performance", Academy of Management Journal, 38, 635-672.

32. Hutchison, S., \& Garstka, M. L. (1996). "Sources of perceived organisational support: goal setting and feedback", Journal of Applied Social Psychology, 26, 1351-1366.

33. Ichniowski, C., Shaw, K., \& Prennushi, G. (1997). "The effects of human resource management practices on productivity", American Economic Review, 87, 291-313.

34. Jackson, S. E., \& Schuler, R. S. 1995. "Understanding human resource management in the context of organisations and their environments", in J. T. Spence, J. M. Darley, \& D. J. Foss (Eds.). Annual Review of Psychology, vol. 46: 237-264. Palo Alto, CA: Annual Reviews.

35. Kamerman, S.B \& Kahn, A.J 1987, The responsive workplace, New Columbia University Press.

36. Kane, R (2000), "Downsizing, TQM, reengineering, learning organisations and HRM strategy", Asia Pacific Journal of Management, 38(1), 26-48.

37. Kemske, F (1998), "HR 2008: A forecast based on our exclusive study", Workforce, January, v77 n1 $\mathrm{p} 46$ (12).

38. Koch, M. J., \& McGrath, R. G. (1996),” Improving labour productivity: Human resource management policies do matter", Strategic Management Journal, 17: 335-354.

39. Kotter, J and Heskett, J (1992), Corporate Culture and Performance, Free Press.

40. Lauver, KI J., \& Kristof-Brown, A. (2001). "Distinguishing between employees' perceptions of person-job and person-organisation fit", Journal of Vocational Behaviour, 59, 454-470.

41. Lepak \& Snell, 1999 "The human resource architecture: toward a theory of human capital allocation and development", Academy of Management Review, Jan 1999 v24 i1 p31 (1)

42. Levine, D. 1995, Reinventing the workplace: How business and employers can both win, Washington, DC: Brookings Institution.

43. Linstone, H.F \& Turoff, M (1975), "The Delphi Method: Technique and Applications", Reading, MA: Addison-Wesley.

44. MacDuffie, J. P. (1995). "Human resource bundles and manufacturing performance: organisational logic and flexible production systems in the world auto industry", Industrial and Labor Relations Review, 48, 197-221.

45. Messmer, M, (2000), "Orientation programs can be key to employee retention", Strategic Finance, Feb, v81, i8, p 12.

46. Meyer, J.P, \& Allen, N.J, (1991), “A three component conceptualisation of organisational commitment", Human Resource Management Review, 1, p89.

47. Meyer, J.P, Allen, N.J \& Smith, C.A, (1993), "Commitment to organisations and occupations: extension and test of a three component conceptualisation", Journal of Applied Psychology, August v78, n4 p538 (14).

48. Netemeyer, R. G., J. S. Boles, D. 0. McKee and R. McMurrian: 1997, "An Investigation into the Antecedents of Organisational Citizenship Behaviours in a Personal Selling Context", Journal of Marketing, 61, 85-98. 
49. Noe, R. A. (1986). "Trainees' attributes and attitudes: neglected influences on training effectiveness", Academy of Management Review, 11: 4, 736-749.

50. O'Reilly, C. A., Chatman, J. \& Caldwell, D. F. (1991). "People and organisational culture: A profile comparison approach to assessing person-organisation fit", Academy of Management Journal, 34: 487-516.

51. Ostroff, C., \& Bowen, D. E. (2000). "Moving HR to a higher level: HR practices and organisational effectiveness", in K. J. Klein \& S. W. J. Kozlowski (Eds.), Multilevel theory, research, and methods in organisations: foundations, extensions, and new directions, (pp. 211-266). San Francisco: Jossey-Bass.

52. Oakland, S \& Oakland, J.S. 2001, "Current people management activities in world-class organisations", Total Quality Management, Sept 2001 v12 i6 p773.

53. Parker, O \& Wright, L, (2001), "Pay and Employee Commitment: the missing link", Ivey Business Journal, Jan, v65, i3, p70.

54. Perry-Smith, J, \& Blum, T.C, (2000), "Work family Human Resource Bundles and perceived organisational performance", Academy of Management Journal, Dec, v43, i6, p 1107.

55. Pinder, C.C, (1984), Work Motivation, Glenview, IL, Scott, Foresman and Company, p113-131.

56. Pfeiffer, J. 1994. Competitive advantage through people: Unleashing the power of the work force. Boston: Harvard Business School Press.

57. Pfeiffer, J (1998), "Seven practices of successful organisations", California Review, Winter 40 (2), 36-155.

58. Podsakoff, P. M., MacKenzie, S. B., \& Bommer, W. H. (1996). "Transformational leader behaviours and substitutes for leadership as determinants of employee satisfaction, commitment, trust, and organisational citizenship behaviours". Journal of Management, 22, 259-298.

59. Rynes S.L and Barber AE. (1990). "Applicant attraction strategies: An organisational perspective", Academy of Management Review, 15, 286-310.

60. Segal, L.M. \& Sullivan, D.G. (1997), "The growth of temporary services works", Journal of Economic Perspectives, 117-136.

61. Seltzer, J. and Bass, B. M. (1990) "Transformational Leadership: Beyond Initiation and Consideration", Journal of Management, 16, No. 4, 693-703.

62. Settoon, R. P., Bennett, N., \& Liden, R. C. (1996). "Social exchange in organisations: perceived organisational support, leader-member exchange, and employee reciprocity", Journal of Applied Psychology, 81, 219-227.

63. Sheridan, J.E (1992), "Organisational culture and employee retention", Academy of Management Journal, December: v35 n5 p1036 (21).

64. Shore, L. M., \& Tetrick, L. E. (1991). "A construct validity study of the Survey of Perceived Organisational Support", Journal of Applied Psychology, 76, 637-743.

65. Shore, L. M., \& Wayne, S. J. (1993). "Commitment and employee behaviour: comparison of affective commitment and continuance commitment with perceived organisational support", Journal of Applied Psychology, 78, 774-.

66. Snell, S., \& Dean, J. (1992). "Integrated manufacturing and human resource management: a human capital perspective", Academy of Management Journal, 35, 467-504.

67. Snell, S., \& Youndt, M. (1995). "Human resources management and firm performance", Journal of Management, 21, 71 1-738.

68. Solomon, C.M (1992), "The loyalty factor", Personnel Journal, September, p52.

69. Solomon, C.M (1999), "Brace for change", Workforce, January, v78 i1 p 6(5).

70. Stein, N, (2000), "Winning the war to keep top talent: Yes you can make your workplace invincible!" Fortune, May, v141, i11, p132.

71. Stone Fish, L., \& Busby, D. M. (1996). "The Delphi method”, in D. H. Sprenkle \& S. M. Moon (Eds.). Research methods in family therapy. NY: Guildford.

72. Stoner-Zemel, M. J. (1988) "Visionary Leadership, Management, and High Performing Work Units: An Analysis of Worker's Perceptions", Doctoral Dissertation, University of Miss.

73. Stum, D (1998), "Five ingredients for an employee retention formula" (Special Report on Recruitment \& Retention), HR Focus, Sept: v75 n9 pS9 (2).

74. Tsui, A. S., Pearce, J. L., Porter, L. W., \& Tripoli, A. M. (1997). "Alternative approaches to the employeeorganisation relationship: does investment in employees pay off?”, Academy of Management Journal, 40, 1089-1121. 
75. Ulrich, D, (1996), Human Resource Champions. Boston: Harvard University Press.

76. Walker, J.W Walker (2001), "Perspectives", Human Resource Planning, March v24 i1 p6.

77. Wallace, J.E, (1997), "Becker's side-bet theory of commitment revisited: is it time for a moratorium or a resurrection?", Human Relations, June v50 n6 p727 (23).

78. Wayne, S. J., Shore, M., \& Liden, R. C. (1997). "Perceived organisational support and leader-member exchange: a social exchange perspective", Academy of Management Journal, 40, 82-111.

79. Whitener, E.M, (2001), "Do 'high commitment' human resource practices affect employee commitment? A cross-level analysis using hierarchical linear modelling”, Journal of Management, Sept-Oct 2001 v27 i5 p515.

80. Wilk SI, Desmarais LB, Sackett PR. (1995). "Gravitation to jobs commensurate with ability: Longitudinal and cross-sectional tests", Journal of Applied Psychology, 80, 79-85.

81. Wilk SI, Sackett PR. (1996). "Longitudinal analysis of ability job complexity fit and job change", Personnel Psychology, 49, 937-967.

82. Williams M and Dreher G, (1992), "Compensation systems attributes and applicant pool characteristics", Academy of Management Journal, 4 35. 571-595.

83. Yammarino, F.J, and Bass, B.M, (1990), "Transformational leadership and multiple levels of analysis", Human Relations, (43), 975 - 95.

Notes 
Notes 